\title{
Digital India and Cashless Economy: towards \$5 Trillion Indian Economy
}

\author{
Gayathri T N
}

\begin{abstract}
Government initiatives is to move towards digital India with less cash economy and reaching GDP \$ 5 trillion economy in next 5 years is the ambitious plan that India is marching with. Consequent to demonetization in November 2016 there was huge drive for cashless transaction. The Digital India started in July 2015 mainly focus on three areas mainly digital infrastructure and empowerment, corporate governance and cater to services on demand. Although there are lot of progress in digital and cashless transaction will these enable to improve the GDP to reach \$5 trillion by 2025 need to be evaluated. In this article, every attempt is made to see how cashless transaction and digital initiatives have moved ahead and will all of these help in improving the GDP of India towards $\$ 5$ trillion economy. The current study will also focus the current India's GDP level with other top 20 economies of the world.
\end{abstract}

Keywords: Cashless payment, digital transaction, demonetization, GDP of India, digital India.

\section{INTRODUCTION}

$\mathrm{D}$ igital India is the flagship initiative started in July 2015 by Government of India with an ambition to turn around India into a knowledge and empowered Society. The mission of digital and cashless economy gained momentum with the announcement of demonetization in November 2016. India is largely cash based economy. According to statistics about $90 \%$ of our work force are from unorganized sector mainly earning their income in cash. The rate of cash to GDP in India is about $12 \%$ in contrast to other large developed economies in which cash to GDP ratio is about 5\%. As per 2015 statistics, about 78\% payments made in India were in cash against the developed countries like the US stood at $20 \%$ and in UK it was at $25 \%$.

\section{WHY SHOULD WE MOVE TOWARDS CASHLESS ECONOMY?}

Cashless economy completely reduces the cash circulation in the economy. Payment made by the way of credit cards, debit cards, bank transfer or virtual wallets etc. are the different ways of cashless transfer. Cashless economy can reduce the rate of corruption and black money in the country. Today low-income households get credit through different informal systems like private lender. By shifting them to

Revised Manuscript Received on December 05, 2019.

* Correspondence Author

Gayathri T N*, Research Scholar, Department of Commerce, Anna Adarsh College for Women, Chennai, India (Assistant Vice-president, Matrix Business Services India Pvt Ltd, Chennai) cashless payment mode help us formalizes this category also in the formal economy. Cashless payments moves the country towards crime free economy. In the advance countries like US the crime rate fell by about $10 \%$ when all the social security schemes were routed through electronic transfer. The Government however, has to have complete control on all the online and cyber scam. The Cashless economy enable us to track all the financial transaction there by increasing the tax base in the country. When a country is moving toward cashless economy, the country can expect boost in the economic growth there by increase in the GDP. In the developed country like US card usage has helped in increasing the spending by $\$ 296$ billion from 2011 to 2015 thereby contributing to the increase in the GDP. If people spend more, job creation increases, thereby reduces unemployment.

While we move towards cashless economy Government has to take adequate care to protect payment system from cyber-attacks.

\section{IS INDIAN ECONOMY READY WITH THE CASHLESS ECONOMY?}

- As on September 2016 as per TRAI around 82\% Citizen own mobile phone.

- Government of India is taking all steps to move towards cashless economy. Some of such initiative were demonetization, transfer of direct Government cash benefits, BHIM etc.

- To promote cashless economy Government ran the DigidhanCampaign.

- To bring in behavioral change among citizen referral and cash back scheme were introduced for BHIM users and merchants.

- After demonetization, there were 100\%: growth day after day in customer enrolment with leading mobile wallets.

- More than 30\% increase in the app usage and about $50 \%$ increase in the download of apps after demonetization.

- India is seeing a great revolution in e commerce and app based activities. The cab aggregators and food aggregators are encouraging the users to make digital payment for their various services.

In the coming years we can see less cash India growing and more and more cashless transaction will be in place. 


\section{DIGITAL INDIA PROGRAMME}

This programme aim is to move India into digitally powerful economy. This programme has changed the digital profile of India.

As per the research conducted by Mckinsey and Company has revealed that

- India is in the 2 nd fastest phase of digital adoption among 17 mature and developing economies

- Public digital initiatives like Aadhar, UPI etc have moved us to adopt digital platforms faster.

The report also has identified 30 digital themes in nine key areas and if the same is accelerated will help us create $\$ 1$ trillion in economic value by 2025 .

India has seen large scale digital transformation from 2013 to 2018

Table - 1: Government Initiatives:*

\begin{tabular}{|l|c|c|}
\hline \multicolumn{1}{|c|}{ Particulars } & $2013-14$ & $2018-19$ \\
\hline Aadhar - Unique biometric access & 510 million & 1.22 billion \\
\hline Aadhar linked bank account & 55.8 million & 870 million \\
\hline e-Government transactions & 6.5 million & 98 million \\
\hline $\begin{array}{l}\text { Common service center's } \\
\text { providing e- services }\end{array}$ & 63,000 & $\begin{array}{c}2,92,748 \\
\text { (As on April } \\
2018)\end{array}$ \\
\hline Aadhar authenticate transactions & 249 million & 2.67 billion \\
\hline
\end{tabular}

Table - 2: Business Initiatives:*

\begin{tabular}{|l|c|c|}
\hline \multicolumn{1}{|c|}{ Particulars } & $\mathbf{2 0 1 3}$ & $\mathbf{2 0 1 8}$ \\
\hline Internet subscribers & 238.7 million & 560 million \\
\hline Social media users & 90 million & 294 million \\
\hline Whats app users & 30 million & 200 million \\
\hline e-commerce users & 40 million & 176.8 million \\
\hline $\begin{array}{l}\text { Digital payment transaction via } \\
\text { (wallet, online banking, credit and } \\
\text { debit card, POS ) }\end{array}$ & 2.5 billion & 24.3 billion \\
\hline
\end{tabular}

*Notes:

1. All Figures as on 22nd January 2019, Common services centre data and Aadhardata compared with 2014

2.Digital payment data is between Jan to Dec 2018 and compared with Financial Year 2013-14. All other figures compared with 2017-18 to 2013-14.

3. Source : Telecom Regulatory of India, UIDAI,India's B2C e-com report - 2016, E-commerce foundation: payment indicators, whatsapp:National monthly progress report, RBI: Electronic transaction aggregators and Analysis layer, Common service scheme, Nov- 2017, Ministry of Electronics and IT - Annual report

India's digital aspiration is broadly classified into 3 Digital ambition being foundation, reach and value. India aimat being a digital factory of the world.

The thirty themes digital in the below broad areas will enable India to achieve $\$ 1$ trillion by 2025

1. Enhance IT Infrastructure and software capabilities reskilling the workforce and robust cyber security laws.

2. E-governance for the future - Government E-market place to be adopted by all Governmental departments. Direct transfer of Government benefits to eliminate inefficiency.

3. Health care benefits to all the citizens of India

4. Quality education - through online learning, continuous assessment system and well educated support system with qualified teacher.

5. Energy to all the citizen of India - Optimization of renewable energy using digital technology and Grid automation.

6. Moving towards next generation financial servicesDigital payment system across government, business and consumer thereby enabling movement towards cashless economy.

7. Doubling income for the farmers -Leveraging on wholesale market, precision agriculture, digital farming and insurance pay-out.

8. Skill development and Job for the future - Investment by Business Process Outsourcing business in small area /town and in semi-urban India. Improving the quality of education in collaboration with industry all this will enable skill improvement and more jobs in future.

9. End to end e- enabled trade across manufactures, SMEs, wholesaler and retailers. Boost manufacturing and exports with theme of Makeall items in India, make for all Indians and make Indian product for the world.

\section{Table - 3: As per 2017 data, India is the second fastest digital adopter among 17 digital economies}

\begin{tabular}{|l|c|c|}
\hline \multicolumn{1}{|c|}{ Country } & $\begin{array}{c}\text { Digital index adoption } \\
\text { Score ranging (0-100) In } \\
\mathbf{2 0 1 7}\end{array}$ & $\begin{array}{c}\text { percentage growth } \\
\text { from 2014 to 2017- } \\
\text { In digital adoption } \\
\text { index }\end{array}$ \\
\hline South Korea & 75 & 31 \\
\hline Sweden & 73 & 27 \\
\hline United Kingdom & 67 & 30 \\
\hline Singapore & 67 & 24 \\
\hline United States & 66 & 30 \\
\hline Australia & 66 & 25 \\
\hline Canada & 65 & 25 \\
\hline Russia & 64 & 44 \\
\hline Japan & 64 & 43 \\
\hline Germany & 61 & 44 \\
\hline France & 58 & 35 \\
\hline Italy & 57 & 36 \\
\hline Brazil & 50 & 30 \\
\hline China & 47 & 45 \\
\hline Indonesia & 40 & 99 \\
\hline South Africa & 40 & 35 \\
\hline India & 32 & 90 \\
\hline
\end{tabular}

\section{Notes:}

* Digital adoption index means the level at which digital application has been done by government, business and individual in 17 economies. The framework was on 30 different metrics classified into three digital pillars namely foundation, reach and value. Detailed analysis conducted to derive the relative importance of all the three digital parameter- 0.37 for foundation, 0.33 for reach and 0.30 for value.For the three parameter equal value was assigned for each of the elements. Indicators normalized to a scale of 0-100 (o being the lowest value). Simple average was taken to calculate the index.

Source: UN e-Government survey; strategy Analytics; Akamai state interne report Q1 2014 and Q1 2017;Ovum; we are social; World Bank; Open signal; International telecommunication union; Analysis mason; Euro monitor International consumer of finance and retailing overview 2017 data edition; Digital adoption index; Strategic Analytic.

Published By: 
India's growth rate has been high across the three parameters of digital index. A strong telecom and technology foundation is very critical and important for emerging Indian economy.

\section{GDP\$ 5 TRILLION INDIA ECONOMY BY 2024 WAY AHEAD}

Indian economy is moving in the right direction. India's nominal GDP in 1996 was around \$ 388 billion and within 10 years in 2006 the GDP reached \$ 920 billion. Again, the GDP almost doubled in 2016 and reached $\$ 2.3$ trillion. In the same tread reaching \$ 5 trillion GDP by 2024-25 is not an uphill task. To move towards the target, India should grow with an average annual growth rate of approx $11.5 \%$ in dollar terms in the next five years. India's growth to this $\$ 5$ trillion GDP targeted to be achieved is in terms of dollar hence, these variables will impact in achieving the growth rate one being the inflation and the other being the Rupee-dollar exchange rate. India's inflation (consumer price index) has been under control and has been around 4 per cent since August 2018. The rupee and dollar exchange rates need to be under control to reach the target of $\$ 5$ trillion. If rupee deplete it will result in adverse effect in India's GDP and if rupee appreciate it will be easier to achieve the target.

The below table gives analysis of GDP growth from FY 2014 to FY 2019

Table - 4: Analysis of GDP growth from FY 2014 to FY 2019

\begin{tabular}{|c|c|}
\hline *Financial Year & $\begin{array}{c}\text { Average growth rate of 8\% GDP (All } \\
\text { figures in dollars \$) }\end{array}$ \\
\hline 2014 & 1.9 trillion \\
\hline 2015 & 2.0 trillion \\
\hline 2016 & 2.1 trillion \\
\hline 2017 & 2.3 trillion \\
\hline 2018 & 2.7 trillion \\
\hline 2019 & 2.8 trillion \\
\hline
\end{tabular}

*Source: MOSPI

Table - 5: Projected GDP to achieve $\$ 5$ trillion by 2024-25

\begin{tabular}{|c|c|}
\hline *Financial Year & $\begin{array}{c}\text { Average projected growth rate of 11.5\% } \\
\text { GDP (All figures in dollars \$) }\end{array}$ \\
\hline 2020 & 3.1 trillion \\
\hline 2021 & 3.4 trillion \\
\hline 2022 & 3.8 trillion \\
\hline 2023 & 4.3 trillion \\
\hline 2024 & 5.0 trillion \\
\hline
\end{tabular}

*Source: MOSPI

Indian GDP is currently at about Rs.190 lakh crore (2018-19) which translates to dollar 2.8 trillion, (dollar conversion isby taking the average exchange rate in that financial year). This only means if Indian economy almost double its size in next five years then GDP willachieve the target of $\$ 5$ trillion.
Table - 6: Overview of world's top 20 economies GDP. (Trillion will be marked as " $T$ " and Billion will be marked as" B")

\begin{tabular}{|c|l|c|c|}
\hline $\begin{array}{c}\text { Sl } \\
\text { No }\end{array}$ & \multicolumn{1}{|c|}{ Country } & Nominal GDP & $\begin{array}{c}\text { GDP based } \\
\text { on PPP }\end{array}$ \\
\hline 1 & The United States & $\$ 19.39 \mathrm{~T}$ & $\$ 19.39 \mathrm{~T}$ \\
\hline 2 & China & $\$ 12.01 \mathrm{~T}$ & $\$ 23.15 \mathrm{~T}$ \\
\hline 3 & Japan & $\$ 4.87 \mathrm{~T}$ & $\$ 5.42 \mathrm{~T}$ \\
\hline 4 & Germany & $\$ 3.68 \mathrm{~T}$ & $\$ 4.17 \mathrm{~T}$ \\
\hline 5 & United Kingdom & $\$ 2.62 \mathrm{~T}$ & $\$ 2.91 \mathrm{~T}$ \\
\hline 6 & India & $\$ 2.58 \mathrm{~T}$ & $\$ 2.61 \mathrm{~T}$ \\
\hline 7 & France & $\$ 2.05 \mathrm{~T}$ & $\$ 3.24 \mathrm{~T}$ \\
\hline 8 & Brazil & $\$ 1.93 \mathrm{~T}$ & $\$ 2.31 \mathrm{~T}$ \\
\hline 9 & Italy & $\$ 1.65 \mathrm{~T}$ & $\$ 1.76 \mathrm{~T}$ \\
\hline 10 & Canada & $\$ 1.53 \mathrm{~T}$ & $\$ 2.02 \mathrm{~T}$ \\
\hline 11 & South Korea & $\$ 1.52 \mathrm{~T}$ & $\$ 4.01 \mathrm{~T}$ \\
\hline 12 & Russia & $\$ 1.38 \mathrm{~T}$ & $\$ 1.24 \mathrm{~T}$ \\
\hline 13 & Australia & $\$ 1.31 \mathrm{~T}$ & $\$ 1.77 \mathrm{~T}$ \\
\hline 14 & Spain & $\$ 1.15 \mathrm{~T}$ & $\$ 2.45 \mathrm{~T}$ \\
\hline 15 & Mexico & $\$ 1.01 \mathrm{~T}$ & $\$ 3.24 \mathrm{~T}$ \\
\hline 16 & Indonesia & $\$ 849.48 \mathrm{~B}$ & $\$ 2.17 \mathrm{~T}$ \\
\hline 17 & Turkey & $\$ 825.75 \mathrm{~B}$ & $\$ 916.07 \mathrm{~B}$ \\
\hline 18 & Netherlands & $\$ 678.57 \mathrm{~B}$ & $\$ 517.17 \mathrm{~B}$ \\
\hline 19 & Saudi Arabia & Switzerland & \\
\hline 20 & & & \\
\hline
\end{tabular}

Note: list above is based on IMF's - World Economic Outlook Database, dated April 2018.

- Nominal GDP = gross domestic product in the current prices and in U.S. dollars

- GDP based on Purchasing Power Parity $(\mathrm{PPP})=$ Gross domestic product is based on PPP valuation - country GDP at current dollar rate

- GDP per capita at current prices prevailing, U.S. dollars rate

The top ten economies contribute about $67 \%$ of the total world economy and top twenty economies contribute to $81 \%$ of world economy. India is one of the fastest growing economy and is in the sixth-position and largest in nominal GDP of dollar 2.61 trillion. India expected to reach 5thpositionovertaking the U K by 2019 according to the IMF projection. India's population drags its nominal Gross Domestic Product to $\$ 1,982$. In 1980 the Indian economy nominal GDP was just $\$ 189.438$ billion and ranked in thethirteen place as per the global list.

\section{CONCLUSION}

India began its journey as an agricultural nation. Over the years India emerged as strong player in manufacturing and services sector. Service sector is among the fastest growing sector of the world. It contribute nearly $60 \%$ of Indian economy and the sector contributes $28 \%$ of employment generation in India. Manufacturing always remains as a crucial sectors and this need to be pushed via various initiatives such as "Make India" concept.

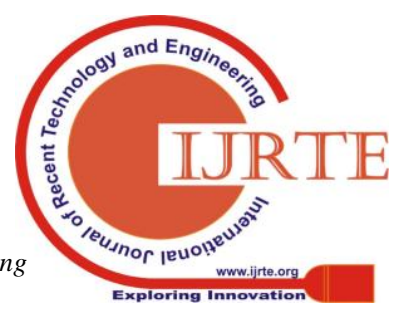


Contribution by the agricultural sector was down by about $17 \%$, but it is still higher compared to other western nations. The strength of the economy depends on more exports, high level of savings, favorable demographic factors and rise in middle class. The Economic Survey's blueprint suggest that for achieving US\$5 trillion economy by 2024-25 there should be a sustain GDP growth rate of $8 \%$ and general International experience of high growth in East Asian economies suggests that such ambitious growth US\$5 trillion economy can only be achieved by a 'virtuous cycle' of savings, investment and exports supported by favorable demographic conditions.

\section{REFERENCES}

1. https://www.mbauniverse.com/group-discussion/topic/business-economy/ cashless-economy

2. https://www.oliveboard.in/blog/cash-to-cashless-digital-india-economy-an alysis-upsc-ias-current-affairs-gk-exam-study/

3. https://www.motilaloswal.com/article.aspx/1121/Why-Going-Cashless-IsGood?-Lets-Understand-the-Benefits

4. https://economictimes.indiatimes.com/news/economy/policy/view-a-5-trill ion-economy-is-a-stretch-do-we-have-the-running-legs/articleshow/70182 080.cms

5. https://www2.deloitte.com/content/dam/Deloitte/in/Documents/technolog y-media-telecommunications/in-tmt-digital-india-unlock-opportunity-noe xp.pdf

6. https://www.indiatoday.in/diu/story/how-can-india-become-a-5-trillion-ec onomy-by-2024-1560008-2019-07-01

7. https://meity.gov.in/writereaddata/files/india_trillion-dollar_digital_oppor tunity.pdf

8. https://www.investopedia.com/insights/worlds-top-economies/

\section{AUTHOR PROFILE}

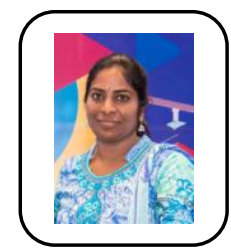

T N Gayathri, Pursuing Doctoral degree Ph.D (part time): in Commerce from Madras University under broad area of Corporate Governance. F.C.S - Member of the Institute of Company Secretaries of India passed out in December 1997. ACMA - Associate Member of the Institute of Cost Accountant of India passed out in June 1995 along with graduation. B.Com Completed in June 1995 in First class from Ethiraj College, Affiliated to University of Madras. Certified lead auditor - ISO -27001, Certified Corporate Director issued by Institute of Directors. Total 24 years of experience in the areas of Operation, Commercial, Accounts / Finance \& as Company secretary. Currently working as Assistant Vice president in Matrix Business services India Pvt Ltd. Instrumental in setting up process BPO with 500 plus employee and defining well established process with adequate automation. 